Revue bibliographique pour le domaine irano-aryen

\title{
Michał Marciak. "Royal Converts from Adiabene and Jewish Identity in the Second Temple Period"
}

\section{Leonardo Gregoratti}

\section{OpenEdition}

1 Journals

\section{Electronic version}

URL: http://journals.openedition.org/abstractairanica/49703

DOI: 10.4000/abstractairanica.49703

ISBN: 1961-960X

ISSN: 1961-960X

Publisher:

CNRS (UMR 7528 Mondes iraniens et indiens), Éditions de l'IFRI

Electronic reference

Leonardo Gregoratti, "Michał Marciak. "Royal Converts from Adiabene and Jewish Identity in the Second Temple Period"', Abstracta Iranica [Online], Volume 40-41 | 2019, document 36, Online since 30 October 2019, connection on 24 April 2021. URL: http://journals.openedition.org/abstractairanica/ 49703 ; DOI: https://doi.org/10.4000/abstractairanica.49703

This text was automatically generated on 24 April 2021.

Tous droits réservés 


\title{
Michał Marciak. "Royal Converts from Adiabene and Jewish Identity in the Second Temple Period"
}

\author{
Leonardo Gregoratti
}

\section{REFERENCES}

Michał Marciak. "Royal Converts from Adiabene and Jewish Identity in the Second Temple Period", BibAn, 8/4, 2018, p. 607-624

1 In this paper the author, a specialist of history and antiquities of Adiabene, a minor Parthian kingdom whose kings converted to Judaism in 1st century CE, analyses the concept of Jewish identity in the second temple period. He takes as an example the socalled "Adiabene Narrative", that is to say, Flavius Josephus' account of the conversion to Judaism of the Royal House of the North Mesopotamian Parthian kingdom. The narrative fits perfectly with the model of "Ethnicity", according to which the conversion implies not only the adoption of the religious creed but also of the cultural features and customs, which are felt as ethnically Jewish. The long-lasting effects of the conversion through generations prove that crossing the cultural boundary with success was possible. The "breaking motif" of the narrative, that is to say, the strong negative reaction of the Parthian/Adiabenian ethnos to the conversion of its leaders, constitutes a problem for those who theorize a situation in which multiple ethnicities can coexist (model of dual/multiple/nested ethnicities). The author argues that classical sources tend to ignore the dynasts' conversion or link to Judaism, depicting the Adiabene royalty as a fundamental political entity within the Parthian empire. Strong connections between his members and the Great King are attested many years after the conversion. This circumstance suggests that the "breaking motif" envisaged by Josephus is, in reality, a mere literary topos aimed at targeting foreign customs. If we 
accept this interpretation, the model of dual/multiple/nested ethnicities concerning Jewish identity remains valid.

\section{AUTHORS}

\section{LEONARDO GREGORATTI}

Durham University 